Teosofia: Indonesian Journal of Islamic Mysticism, Vol. 8, No. 2, 2019, pp. 159-174 e-ISSN: 2540-8186; p-ISSN: 2302-8017

DOI:

\title{
The Spirit of Reciprocity Verses in The Quran as A Solution To Counter Religious Radicalism
}

\author{
Muhamad Ali Mustofa Kamal \\ Universitas Sains Ilmu Al-Qur'an (UNSIQ), Wonosobo \\ Email: musthofakamal@unsiq.ac.id
}

\begin{abstract}
:
The diversity of religions necessitates the recognition and respect of religions other than ours. Islam is a religion that is peaceful and full of love. The spread of radicalism in religious communities in Indonesia illustrates the lack of tolerance in the recognition of religious diversity and the religious diversity of others. This literary research uses a qualitative approach with content analysis and comprehensive interpretation for the Qur'anic text about reciprocity verses. This study concludes that the Qur'an provides enthusiasm and solutions in terms of management and counteracts religious radicalism in the spirit of 'mutual'. Recitation of reciprocal verses as illustrated by the Quran with the editorial and unique arrangement of language in the al-Nisa' verse 86 and al-An'am verse 108 provides a 'mutual' solution. The principle of mutual respect (al-Nisa': 86) and not berating each other (al-An'am: 108) with a better attitude in religious life.
\end{abstract}

Keyword: diversity, religious radicalism, mutual, verse reciprocity, radicalism solution

\section{A. Introduction}

$\mathrm{T}$

The diversity of Indonesian people is considered as a wealth or privileges for the Indonesian people. ${ }^{1}$ The phenomenon of the many riots between religions whereas in the religion itself teaches peace. The religion of Islam it is explained that it is strictly forbidden for Muslims to do wrong against other religions. Allah said "Allah does not forbid you to do good and be fair to those who do not fight you because of religion and do not (also) expel you from your country. Surely Allah likes those who act fairly" (QS. Al-Mumtahanah: 8)". In Indonesia, there are many religions and beliefs held by every Indonesian community including Hinduism,

Muhamad Ali, "Muslim Diversity: Islam and Local Tradition in Java and Sulawesi, Indonesia," Indonesian Journal of Islam and Muslim Societies, 2011, https://doi.org/10.18326/ijims.v1i1.1-35. 
Buddhism, Islam, Christianity, Catholicism, and Confucianism. ${ }^{2}$ With various religions there are many religious holidays that make life alive in Indonesia. It should be proud that we as Indonesian society have differences in the field of Religion. In addition, Indonesia become a country that is somewhat unique because it has so many diversities, so it is known as a country with a lifestyle order plural and plural society. Of course, we can already see in the Indonesian motto "Unity in Diversity". ${ }^{3}$ The existence of the word "bhineka" yang means "different" in the motto of this country is a recognition that the Indonesian nation is a nation that is "different" in the sense of being a nation that has a unique characteristic that is pluralist. ${ }^{4}$

Every gate created in interfaith relations indeed creates a unique relationship. But keep in mind that throughout religious history has a "double face". ${ }^{5}$ This is understood in the sense that religions can bring life to life in the community and state, but at the same time can also damage life itself. The double face of this religion on the other hand is a source of inspiration and a spirit for peace and reconciliation, but also at the same time as inspiration and spirit for the power of war and disrupting and even killing lives. Thus, each special and unique relationship also has two kinds of traits and characters namely "soft" and "hard". 6 As has been said above that the dual face of religion that gives birth to its nature and character plays a role in determining the model of relationships created between religions. We can clearly see that there are two models of relationships in encounters as result in interreligious relations. ${ }^{7}$ The first model is a relation framed in a calm encounter and colored by cooperation between the two. Then the second model is framed in an encounter colored by various conflicts, both verbal and literary. ${ }^{8}$

The face of religion that looks hard, is colored by various conflicts both verbal and literature as the second model, will eventually bear the seeds of radicalism in religious relations. ${ }^{9}$ The essence of radicalism is the attitude and actions of a person or

2 Lene Pedersen, "Religious Pluralism in Indonesia," Asia Pacific Journal of Anthropology, 2016, https://doi.org/10.1080/14442213.2016.1218534.

3 Luis Lugo et al., “The World's Muslims : Unity and Diversity,” Pew Research Center, 2012.

4 Muhamamad Fakri, “Wawasan Kerukunan Beragama Di Indonesia,” Agama, 2013.

5 Michael O’Neill, “'A Double Face of False and True': Poetry and Religion in Shelley,” Literature and Theology, 2011, https://doi.org/10.1093/litthe/frq067.

6 Johan Galtung, "Religions Hard and Soft," in The Ashgate Research Companion to Religion and Conflict Resolution, 2012.

7 Sumanto Al Qurtuby, “A Camouflage for Religious Violence,” Jakarta Globe, 2012.

8 Jeneman Pieter and John A Titaley, "Hubungan Antar Agama Dalam Kebhinekaan Indonesia (Studi Kasus Terhadap Hubungan Warga Jemaat GPIB Tamansari Pospel Kalimangli Dengan Warga Muslim Di Dusun Kalimangli),” Waskita: Jurnal Studi Agama Dan Masyarakat, 2013.,p.26

9 Noorhaidi Hasan, "Reformasi, Religious Diversity, and Islamic Radicalism after Suharto," Journal of Indonesian Social Sciences and Humanities, 2008. 
a certain group that uses violent methods in bringing about the desired change. Radical groups generally want these changes in a short time and drastically and contrary to the prevailing social system. Radicalism is often associated with terrorism because radical groups can do anything, they can to achieve their desires, including terrorizing those who disagree with them. Although many associate radicalisms with certain religions, basically radicalism is a political problem and not the teachings of religion. ${ }^{10}$ In the discussion of this paper, the author describes interesting findings in the study of the verses of the Quran in the form of a common thread on the phenomenon of radicalism in religion that is increasingly mushrooming. The identification of reciprocal verses in the Quran that speaks and is displayed with unique and extraordinary language narratives, both psychologically and socially culture, seems to provide a spirit of tolerance and deradicalization to care for interfaith relations and religious understanding, especially Islam. This literary research uses a qualitative approach with content analysis and comprehensive interpretation for the Qur'anic text about reciprocity verses.

\section{B. Religious Radicalism: A Portrait of Religious Misunderstanding}

The Radicalism has existed since time immemorial because it already exists in humans. Actually, what is the meaning of radicalism? According to experts, Understanding Radicalism is an ideology (ideas or ideas) and understandings that want to make changes to the social and political system by using violent / extreme methods. ${ }^{11}$ However, the term "Radical" was first recognized after Charles James Fox explained this understanding in 1797. At that time, Charles James Fox called for "Radical Reform" in the government system in Great Britain (England). ${ }^{12}$ The reforms were used to explain the movements that supported the parliamentary revolution in the country. In the end the ideology of radicalism began to develop and then blend with the ideology of radicalism. As mentioned in the notion of radicalism above, radicalism is often associated with certain religions, especially Islam. This can be seen from the existence of ISIS (Islamic State of Iraq and Syria) groups who have carried out terror against several countries in the world by bringing / mentioning the symbols of the

10 C. Dale Walton, "A Review of 'Routledge Handbook of Political Islam," Comparative Strategy, 2012, https://doi.org/10.1080/01495933.2012.665726.

11 Alex Schmid, "Radicalisation, De-Radicalisation, Counter-Radicalisation: A Conceptual Discussion and Literature Review," Terrorism and Counter-Terrorism Studies, 2013, https://doi.org/10.19165/2013.1.02.

12 Daron Acemoglu et al., "The Consequences of Radical Reform: The French Revolution," American Economic Review, 2011, https://doi.org/10.1257/aer.101.7.3286. Look at: D.S., "Charles James Fox," Notes and Queries, 1865, https://doi.org/10.1093/nq/s3-VIII.201.370-b.

Teosofia: Indonesian Journal of Islamic Mysticism, Vol. 8, No. 2, 2019 
Islamic religion in each of their acts of terror. ${ }^{13}$ ISIS's actions and the support of a small number of Muslims towards ISIS eventually made some of the world community consider ISIS a picture of Islamic teachings. ${ }^{14}$ But of course, this is not true because most Muslims actually condemn the heinous actions carried out by ISIS, and open the eyes of the world that the original Islam condemned the ideology of radicalism itself. Islam itself is a religion of peace conveyed by the Prophet peacefully. ${ }^{15}$

The term radicalism is often associated with the phenomenon of terrorism because radical groups can do anything, they can to achieve their desires, including efforts to terrorize those who disagree with them. ${ }^{16}$ A radical is a person who favors rapid and sweeping changes in laws of governments. Although many party's associate radicalism with certain religions, basically the ideology of radicalism is based on political problems and misunderstanding of religion and not the teachings of religion. Radicalism is very easy to recognize. That is because in general these adherents of ideology want to be known / famous and want to get the support of more people. That is why radicalism always uses extreme methods. The following are the characteristics of radicalism:

1. Radicalism is a response to conditions that are happening, the response is then manifested in the form of evaluation, rejection, and even opposition with a loud.

2. Carry out continuous rejection efforts and demand the desired drastic changes occur.

3. People who embrace radicalism usually have a strong belief in the program they want to run.

4. Adherents of radicalism do not hesitate to use violence in realizing their desires.

5. Adherents of radicalism have the assumption that all parties with different views are guilty.

From the explanation of the features of the ideology of radicalism above, the main factors causing and triggering it are problems of religious misunderstanding which then take root in other problems. As for several factors that cause radical ideology stuck in someone:

13 Jay Sekulow, "The Rise of ISIS and the New Caliphate," in Rise of ISIS: A Threat We Can't Ignore, 2014.

14 Axel Heck, "Images, Visions and Narrative Identity Formation of ISIS," Global Discourse, 2017, https://doi.org/10.1080/23269995.2017.1342490.

15 NURUL FAIQAH and TONI PRANSISKA, "Radikalisme Islam Vs Moderasi Islam: Upaya Membangun Wajah Islam Indonesia Yang Damai,” Ejournal.Uin-Suska.Ac.Id, 2018.

16 Ömer Taşpınar, "Fighting Radicalism, Not 'Terrorism': Root Causes of an International Actor Redefined," SAIS Review, 2009, https://doi.org/10.1353/sais.0.0059. 


\section{a) Thought Factors:}

Radicalism can develop because of the idea that everything must be returned to religion even in a rigid and violent manner. Radicalism has basically been associated with those whose school of thought and its subsequent ideological programs are oriented towards drastic and violent change socially and politically. It also is considered identical with extremism; ${ }^{17}$

\section{b) Economic factors:}

Economic problems also play a role in making radicalism understand in various countries. ${ }^{18}$ It is human nature to survive, and when pressed due to economic problems, humans can do anything, including terrorizing other humans. Opportunities that influence the occurrence of religious harmony in this factor indicate that the factors that support the creation of religious harmony, if it does not work properly, a gentle encounter can turn into a hard encounter. The negative impact of information and economic globalization, which is very rapid changes, results in anxiety for religious groups who are not ready to accept the changes that occur. This can cause a backlash against change, so that religious groups become reactive and aggressive. Resulting in violence in the community; ${ }^{19}$

\section{c) Political Factors:}

The thought of some people that a state leader only sided with certain parties, resulted in the emergence of community groups that seemed to want to uphold justice. These groups can be from social, religious, or political groups. Instead of upholding justice, these groups often make matters worse; ${ }^{20}$

\section{d) Social Factors:}

Still closely related to economic factors. Some of the economically weak classes are generally narrow-minded, so it is easy to trust radical figures because they are considered capable of bringing drastic changes to their lives; ${ }^{21}$

17 Umar Basalim, “MENELUSURI AKAR RADIKALISME,” Ilmu Dan Budaya, 2015.

18 Ali A. Mazrui, "Islam, Political Leadership and Economic Radicalism in Africa," Comparative Studies in Society and History, 1967, https://doi.org/10.1017/S0010417500004539.

19 Matthijs Rooduijn and Brian Burgoon, "The Paradox of Well-Being: Do Unfavorable Socioeconomic and Sociocultural Contexts Deepen or Dampen Radical Left and Right Voting Among the Less WellOff?," Comparative Political Studies, 2018, https://doi.org/10.1177/0010414017720707.

20 Tahir Abbas, "A Theory of Islamic Political Radicalism in Britain: Sociology, Theology and International Political Economy," Contemporary Islam, 2007, https://doi.org/10.1007/s11562-0070012-0.

21 David Snow and Remy Cross, "Radicalism within the Context of Social Movements: Processes and Types,” Journal of Strategic Security, 2011, https://doi.org/10.5038/1944-0472.4.4.5. 


\section{e) Psychological Factors:}

Bitter events in one's life can also be a factor causing radicalism. Economic problems, family problems, love problems, hatred and revenge, all of this has the potential to make someone become a radical. On the surface, a decision to join a radical Islamic c movement seems irrational. Participation entails enormous costs and risks, especially if the movement supports the use of violence for the cause. In addition, less controversial options are typically available for those who desire a deeper religious experience. Participants are frequently referred to as "zealots," "fanatics," and "militants," connoting an irrational adherence devoid of reflective logic; 22

\section{f) Education Factors:}

Incorrect education is a factor causing the emergence of radicals in various places, especially religious education. Educators who give teachings in the wrong way can cause radicalism in a person. ${ }^{23}$

Talking about understanding religious radicalism is indeed a complex problem. This is because the existing problems do not only involve one dimension but more. Of course, the emergence of various dimensions or factors that affect interreligious relations is caused by religion not only dealing with itself but also relating to or dealing with "playmates" and patterns of care and thought. According to Magnis Suseno ${ }^{24}$, the cause of a hard encounter in the relationship of religious adherents, whether it is between Islam and Christianity and other religions or vice versa is caused by at least 2 things, First: The existence of hardliners and extreme groups. These groups usually come from fundamentalists; Second: The tendency of leaders and followers in the internal environment of each religion is still to be negative towards different beliefs.

In a country with a pluralistic society like Indonesia, conflicts will always arise, and it is difficult for us to avoid them. In other words, pluralism must be accepted as a reality, accompanied by a positive attitude. Starting from this attitude, the contradictions that arise in the community can be managed properly. The strengthening of the symptoms of religious intolerance is accompanied by the rise of radicalism and religious fundamentalism. Religious intolerance threatens diversity because it is an act of discrimination, neglect, prohibition or preference based on

22 Quintan Wiktorowicz, “Joining the Cause: Al Muhajiroun and Radical Islam," in Roots of Islamic Rad Icalism, 2004.

23 Diego Gambetta and Steffen Hertog, Engineers of Jihad: The Curious Connection between Violent Extremism and Education, Engineers of Jihad: The Curious Connection between Violent Extremism and Education, 2016.

24 Franz Magnis-Suseno, "Christian and Muslim Minorities in Indonesia," in Democracy and Islam in Indonesia, 2015, https://doi.org/10.7312/columbia/9780231161916.003.0004.,p.93 
religion or belief. The result of this intolerance is the elimination or reduction of the recognition or implementation of human rights and fundamental freedoms on the basis of equality. Cases of religious intolerance in Indonesia are generally dominated by violence and attacks, the spread of hatred, restrictions on thinking and belief, heresy and reporting of groups suspected of heresy, restrictions on religious activities or rituals, the imposition of beliefs, and conflicts over places of worship. The need to foster better mutual relations for efforts to re-understand the religious diversity of religious people is one alternative to counteract religious attitudes and ideologies that lead to radicals and extremists.

\section{Reciprocity Verses in The Quran and The Message of Deradicalism}

De-radicalization is the social and psychological process whereby an individual's commitment to, and involvement in, violent radicalization is reduced to the extent that they are no longer at risk of involvement and engagement in violent activity." 25 Thus, de-radicalization is understood as an effort systematic to build public awareness that narrow fanaticism, fundamentalism, and potential radicalism arouse terrorism. Deradicalization can also be understood an effort to neutralize radical ideas through an interdisciplinary approach, such as religion, psychology, law and sociology, aimed at those who are influenced by ideology radical. Whereas in the context of emerging religious radicalism as a result of radical religious understanding, deradicalization is interpreted as the process of rectifying narrow religious understandings, fundamental, be moderate, broad and comprehensive. ${ }^{26}$

In life between human beings, it is necessary in the life of different tribes, because human life consists of various kinds and differences, both in terms of beliefs or religions, tribes, races, diverse languages, different skin types, and nationalities. Therefore, it is necessary not to know each other. In order to be made, this is a place of enmity but to support each other and have gathered all the differences that God has determined to bring about a good and harmonious life between people. The Qur'an explains the principles of 'mutual' and ethics that must be considered, both between religious relations, nation and between groups of people who live in a society, so that they can work together towards a good change in a life together.

Sayyid Qutb said that Islam is a religion that is peaceful, and full of love. It is a system that aims to overshadow all of nature with a shade of peace and love, that humans are gathered under the banner of God with the position as brothers who know

25 Bertjan Doosje et al., "Terrorism, Radicalization and de-Radicalization," Current Opinion in Psychology, 2016, https://doi.org/10.1016/j.copsyc.2016.06.008.

26 Donatella Della Porta and Gary LaFree, "Guest Editorial: Processes of Radicalization and deRadicalization," International Journal of Conflict and Violence, 2012, https://doi.org/10.4119/UNIBI/ijcv.266.

Teosofia: Indonesian Journal of Islamic Mysticism, Vol. 8, No. 2, 2019 
each other in love, and do not berate and antagonize each other. Nothing prevents this direction except the aggression of radical enemies of Allah and enemies of religious action. As for if they are peaceful, Islam is not at all interested in hostilities. ${ }^{27}$ So, the existence of different religions in life, is required to respect each other's followers, even though the religion of Allah is blessed by Islam, but even so God still teaches His servants to continue to give respect and respect to those of different faiths. Like the verses of Allah said in Surah al An'am verse 108 and anal Nisa': 86:

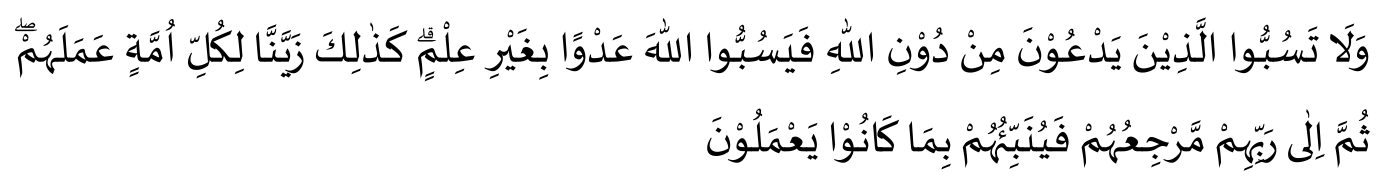

"And do not insult those they invoke other than Allah, lest they insult Allah in enmity without knowledge. Thus, We have made pleasing to every community their deeds. Then to their Lord is their return, and He will inform them about what they used to do."(QS. Al An'am: 108)

This verse gives instructions to Muslims not to scold or denounce non-Muslim worshipers. Because, this can be done by Muslims because they are driven by emotions in facing the disorder of the polytheists or their ignorance. Because, curse or insults will not produce benefits in religion. The prohibition of cursing Gods and other parties' beliefs is a religious requirement, in order to maintain the sanctity of religion, and to create a sense of security and harmonious relations between religious communities. This verse is specifically aimed at Muslims about how to behave in the face of the idolaters. And do not you, O Muslims, curse worship as idols and others that they worship besides Allah, because if you curse it, then they will curse God by going beyond limits or without thinking and without knowledge. Thus, it has become a rule that applies all the time that We make every people consider their work well. They must be held accountable for their actions. Then at the appointed time, to the Lord where they return, then He will tell them what they have done to get the right reward. ${ }^{28}$

Regarding the reason for the decline of this verse is told as follows, once upon a time the Muslims were berating idols, the worship of unbelievers, then they were banned from cursing it. (Hadith of Abd ar-Razzaq from Qatadah). ${ }^{29}$ Allah forbids Muslims from cursing idols worshiped by the polytheists to avoid swearing at Allah from the polytheists, because they are people who do not know the attributes of Allah

27 Sayyid Qutb, Tafsîr Fî Zhilâl Al Qur'an (Cairo: Dar as Syuruq, 1992).,Juz.6, p. 3544

28 Fakhruddin al Razi, Tafsir Al Fakhri Al Razi: Mafatih Al Gaib (Beirut: Dar Al Fikr, 1981).,Jilid 13, p. 147

29 Ibnu Kasir, Tafsir Alquran Al Adhim, Juz 4 (Beirut: Dar Al Fikr, 2005)., Jilid 2, p.686 
and the titles, they should say to Him. ${ }^{30}$ Then it can happen that they berate Allah with words that cause the anger of believers. From this verse an understanding can be made that if an action is used to realize other immoral acts, then it should be abandoned, and all actions that cause bad consequences, then the action is prohibited. This verse also signals to the prohibition of Muslims that they should not do anything that causes the infidels to stay away from the truth. Abusing idols is actually abusing inanimate objects. Therefore, cursing idols is not a sin. However, because the cursing of the idols causes the polytheists to feel offended and angry, which in the end they will retaliate by abusing God, it is forbidden to do so. God gives an explanation that He makes every people consider their own good deeds. This means that a good measure of whether or not an action or habit, sometimes arises from human judgment itself, whether it is an act or hereditary habit or actions and habits that have just arisen, such as the offense of the polytheists when there are people those who curse their idols. This shows that the criteria for evaluating an act or habit is good or bad, including an issue of endeavor. ${ }^{31}$

Morality is a fundamental component of human cultures and has been defined as prescriptive norms regarding how people should treat one another, including concepts such as justice, fairness, and rights. ${ }^{32}$ It's just that besides that God has given the human instinct to judge the deeds and habits, whether those actions are good or bad. While the duties of the Apostle are the delivery of revelations that guide and direct the instinct to develop accordingly to the right path so that they can judge their actions and habits with the right judgment. At the end of this verse God gives an explanation that the whole person will return to God after they die, that is, on the day of the resurrection; because He is the true God and He will preach all the deeds they have done in the world, and will give a reward in kind. Quraish Shihab explain that the editorial of Al An'am verse 108 is only addressed to the congregation of Muslims, namely: "And do not you, O Muslims," curse worshipers "like idols they worship besides Allah, because if you swear at them" then they will also curse Allah "with the result overstepped or hurriedly without thinking and without knowledge. ${ }^{33}$

The word (سيّوا) (سبّ) the word sabba, that is, the utterance which implies insult to something, or the addition of a deficiency or disgrace on it, whether it is so, even more so if it is not true. ${ }^{34}$ While scholars emphasize that not

30 Muhammad Ali Sabuni, Safwatu Al Tafasir, Jilid 2 (Beirut: Dar Alquran Al Karim, 1999).,Jilid 1, p. 318

31 Fakhruddin al Razi, Tafsir Al Fakhri Al Razi: Mafatih Al Gaib.,p.148

32 Keith J. Yoder and Jean Decety, "The Good, the Bad, and the Just: Justice Sensitivity Predicts Neural Response during Moral Evaluation of Actions Performed by Others," Journal of Neuroscience, 2014, https://doi.org/10.1523/JNEUROSCI.4648-13.2014.

33 M. Quraish Shihab, Tafsir Al Misbah (Jakarta: Lentera Hati, 2002).,p.242

34 Abi Ishaq Ibrahim al Sari, Ma'anil Quran Wa I'rabuhu, ed. Tahqiq: Abdul jalil Abd Sulbi (Beirut: Alam al Kutub, n.d.)., p.280-281

Teosofia: Indonesian Journal of Islamic Mysticism, Vol. 8, No. 2, 2019 
included in the definition of this word blames an opinion or act, it also does not include a misguided evaluation of one religion, if the assessment is sourced from adherents of other religions. This last opinion is of course true, as long as it does not cause a negative impact on society. That this verse prohibits cursing the beliefs of the idolaters, because curses do not produce anything related to the benefit of religion. The religion of Islam comes to prove the truth, while curses are usually pursued by those who are weak. Conversely, swearing may be seen before ordinary people as winners, because of that the loud voice of the climber and tongue defilement is not appropriate for a person, a Muslim who must maintain his tongue and behavior. On the other hand, curses can cause antipathy towards cursing, so that if it is done by a Muslim, then the cursed will be increasingly distant. The prohibition of cursing gods and other parties' beliefs is a religious guidance, in order to maintain the sanctity of religions, and to create a sense of security and harmonious relations between religious communities. ${ }^{35}$ Humans are easily provoked when their religion and beliefs are offended. This is human nature, whatever the social position or level of knowledge, because religion blossoms in the hearts of adherents, while the heart is the source of emotions. In contrast to knowledge, which relies on reason and mind. Because it is easy for someone to change his scientific opinion, but it is very difficult to change his belief even though the evidence of mistaken belief has served him.

The word (عدوا) 'adwan can mean enmity and transgressions, and can also mean run or rush. ${ }^{36}$ The mention of this word here signals that any harassment of religion regardless of religion - is exceeding boundaries and inviting hostility. It does not mean that the Muslims who berate idols or the beliefs of the idolaters do not persecute, as some interpreters suspect. Then his words: "without knowledge" shows that those who denounce religion are essentially devoid of knowledge. If the one he is referring to is a 'haq' religion, then his stupidity is very clear, and if he is calling for a false religion, then he has no knowledge of this prohibition on God. ${ }^{37}$

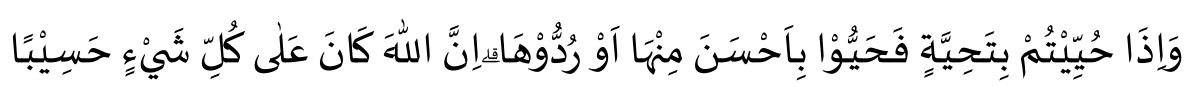

"And when you are greeted with a greeting, greet [in return] with one better than it or [at least] return it [in a like manner]. Indeed, Allah is ever, over all things, an Accountant." (QS. Al Nisa: 86).

The last verse talks about the rewards of being the intermediaries of goodness, and of threatening the intermediaries of evil. Being an intermediary of virtue creates harmonious relationships. The Verse al Nisa: 86 , teaches another way to establish a

\footnotetext{
35 Thomas Wilke, “"Fuck the Gods“: Moral, Religion Und Religiosität,” 2019, https://doi.org/10.1007/978-3-658-11747-4_10.

36 Sari, Ma'anil Quran Wa I'rabuhu.p.281

37 Shihab, Tafsir Al Misbah.,Jilid 4, p.244
} 
closer relationship, that is to pay respect to the same or better. And if you are respected by anyone with a salute, whether in the form of deeds or treatment, then immediately respond to that respect with a better respect, or reply to that honor which is commensurate with the respect that is given. Truly, God takes into account everything concerning the manner and quality of the reverence given. If we pay attention, the verse "salutation" of honor is located in the middle of the verse of war. This could mean to show the fundamental principle of Islam which is "salutation" which means safety and peace. He waged war only to establish peace and salvation on earth with a broad and comprehensive meaning. People are reciprocal if they reward kind actions and punish unkind ones. ${ }^{38}$

An order to behave politely in relationships, so that fraternal relations are maintained by way of establishing an order that is carried out when meeting someone. One must repay the respect given to him in the form of a greeting that he receives with a reward that is worth it or in a better way. ${ }^{39}$ Appropriate or better replies can be in the form of pleasant words or in a gentle voice or in interesting gestures, paying attention to life in upholding manners that strengthen brotherly relations between their neighbors. God pays attention to everything including paying attention to human life in upholding manners that can strengthen the brotherly relationship between their fellowmen.

In line with that verse there are the following hadith: ${ }^{40}$

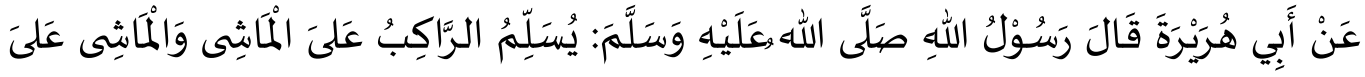

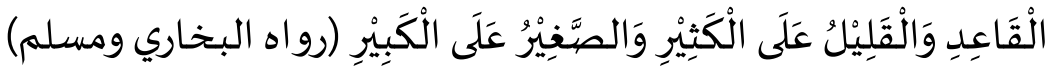

"From Abu Hurairah said, the Messenger of Allah said, "Let those who drive give greetings to those who walk, and those who walk greet those who sit, those who give little greetings to many groups, groups of young people give greetings to the old group." (Narrated of al-Bukhari and Muslim). ${ }^{41}$

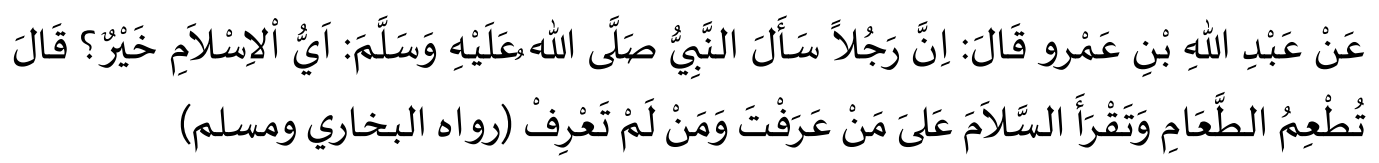

"From Abdullah bin Amr, he said, "that someone asked the Messenger of Allah, which is the best Islamic teachings? Rasulullah SAW answered, "(that is)

38 Armin Falk and Urs Fischbacher, "A Theory of Reciprocity," Games and Economic Behavior, 2006, https://doi.org/10.1016/j.geb.2005.03.001.

39 Sari, Ma'anil Quran Wa I'rabuhu.,Jilid 2, p.86

40 Kasir, Tafsir Alquran Al Adhim.Jilid 1, p.481-482

41 "Mausu'ah Al Hadis Syarif Fi Kutub Tis'ah" (al-Baramij Syirkah islamiyah al Duliyah, n.d.), http://www.almeshkat.net/books/open.php?cat=37\&book=2293.

Teosofia: Indonesian Journal of Islamic Mysticism, Vol. 8, No. 2, 2019 
feeding (to the poor) and greeting those whom you know and those you do not know." (Narrated of al-Bukhari and Muslim). ${ }^{42}$

Affirmation of the meaning of Surah al Nisa: 86: if you are honored with respect, both in the form of words or treatment or gifts and the like, then respond immediately - as understood from the letter fa' on the word (فردومها (فرد) farudduha - that respect with better, i.e. increase or increase its quality or reply to something similar that is not excessive and not reduced. ${ }^{43}$ Verily Allah counts everything including the procedure and quality of greetings or respect. The word (تية) tahiyyah is taken from the word (حياة) 'hayyah' alive. The word tahiyat means prayer to extend life. He was not originally spoken except to the king / ruler. ${ }^{44}$ Even in prayer we are taught to say 'altahiyyat' which is addressed only to Allah SWT. This is to illustrate that life and the unending source of life is Allah Almighty. From here then this word is interpreted as a kingdom, as if the king's life is the perfect life. The word is then used to describe all sorts of reverence, both in the form of utterances and others. ${ }^{45}$ In social interaction, Allah and His Messenger order to spread peace among all members of the community, small or large, known or unknown. When the Prophet Muhammad When asked about good Islamic practices, he said: "Giving food and greeting those you know and those you don't know" (Hadith narrated from Bukhari and Muslim). ${ }^{46}$ It is natural to underline sentences that you do not recognize in the words of the Prophet Muhammad above.

The Qur'anic verses containing phrases on each other in surah al Nisa: 86 and Al An'am 108 which only contain verses that are mutually beneficial in both Islamic and non-Islamic texts. Both of these verses has represented deradicalism as efforts to against religious radicalism. However, seeing the context of correlation (munasabah) and the unique message of the sentence structure in these two verses, contains a soothing message and can be used as evidence for acts of deradicalism, namely mental to support each other and mentally to insult and insult each other. Therefore, it is important to consider both verses that fit the context and purpose of the mark. Mental mutual respect between adherents of religion in various ways, do not berate each other, will give the fundamental effect of 'no matter the most righteous one', blaming the beliefs of others. This attitude will continue to be the spirit of building brotherhood and ties of love between human beings. The spirit and message of these two verses will make each adherent of religion need a process of mutual need and mutual support for

\footnotetext{
42 "Mausu'ah Al Hadis Syarif Fi Kutub Tis'ah."

43 Fakhruddin al Razi, Tafsir Al Fakhri Al Razi: Mafatih Al Gaib.,Jilid 10, p.218

44 Fakhruddin al Razi.,Jilid 10, p. 215

45 Shihab, Tafsir Al Misbah. Jilid 4, P.245

46 Fakhruddin al Razi, Tafsir Al Fakhri Al Razi: Mafatih Al Gaib.Jilid 1, p. 481
} 
one another. Schmid argues that both extremism and radicalism can only be properly assessed in relation to what is mainstream political thought in a given period. ${ }^{47}$

Some Respondents reflected a general perspective that regards social exclusion, Islamophobia, lack of effective theological and political leadership, regressive antiterror law and geo-political events as principal factors in the radicalization and the deradicalization of Society. ${ }^{48}$ Adherents of radicalism cannot see the real reality because they assume that all who disagree with each other are wrong. Generally, use violence and other negative ways in an effort to realize their goals. Adherents of radicalism consider all parties with different views to him are enemies that must be removed. Adherents of radicalism do not care about human rights. The de-radicalization that was intended for changing radical thinking can actually trigger that radicalism itself, so that what is needed is the independence of life in the form economic access and disengagement from violence and radical group identity. ${ }^{49}$ Actualizing the spirit of 'mutual' in the messages of al Nisa: 86 and al An'am: 108 will change and strengthen the principles of tolerance and peace.

\section{Conclusion}

Qur'an provides enthusiasm and solutions in terms of management and counteracts religious radicalism in the spirit of 'mutual'. Recitation of reciprocal verses as illustrated by the Quran with the editorial and unique arrangement of language in the al-Nisa' verse 86 and al-An'am verse 108 provides a 'mutual' solution. The principle of mutual respect (al-Nisa': 86) and not berating each other (al-An'am: 108) with a better attitude in religious life.

47 Schmid, "Radicalisation, De-Radicalisation, Counter-Radicalisation: A Conceptual Discussion and Literature Review."

48 Tahir Abbas and Assma Siddique, "Perceptions of the Processes of Radicalisation and DeRadicalisation among British South Asian Muslims in a Post-Industrial City," Social Identities, 2012, https://doi.org/10.1080/13504630.2011.629519.

49 John Horgan, Walking Away from Terrorism: Accounts of Disengagement from Radical and Extremist Movements, 2009, https://doi.org/10.4324/9780203874738.

Teosofia: Indonesian Journal of Islamic Mysticism, Vol. 8, No. 2, 2019 


\section{Bibliography}

Abbas, Tahir. "A Theory of Islamic Political Radicalism in Britain: Sociology, Theology and International Political Economy." Contemporary Islam, 2007. https://doi.org/10.1007/s11562-007-0012-0.

Abbas, Tahir, and Assma Siddique. "Perceptions of the Processes of Radicalisation and De-Radicalisation among British South Asian Muslims in a Post-Industrial City." Social Identities, 2012. https://doi.org/10.1080/13504630.2011.629519.

Acemoglu, Daron, Davide Cantoni, Simon Johnson, and James A. Robinson. "The Consequences of Radical Reform: The French Revolution." American Economic Review, 2011. https://doi.org/10.1257/aer.101.7.3286.

Ali, Muhamad. "Muslim Diversity: Islam and Local Tradition in Java and Sulawesi, Indonesia." Indonesian Journal of Islam and Muslim Societies, 2011. https://doi.org/10.18326/ijims.v1i1.1-35.

Basalim, Umar. “MENELUSURI AKAR RADIKALISME.” Ilmu Dan Budaya, 2015.

D.S. “Charles James Fox." Notes and Queries, 1865. https://doi.org/10.1093/nq/s3VIII.201.370-b.

Doosje, Bertjan, Fathali M. Moghaddam, Arie W. Kruglanski, Arjan de Wolf, Liesbeth Mann, and Allard R. Feddes. "Terrorism, Radicalization and deRadicalization." Current Opinion in Psychology, 2016. https://doi.org/10.1016/j.copsyc.2016.06.008.

FAIQAH, NURUL, and TONI PRANSISKA. "Radikalisme Islam Vs Moderasi Islam: Upaya Membangun Wajah Islam Indonesia Yang Damai." Ejournal.UinSuska.Ac.Id, 2018.

Fakhruddin al Razi. Tafsir Al Fakhri Al Razi: Mafatih Al Gaib. Beirut: Dar Al Fikr, 1981.

Fakri, Muhamamad. "Wawasan Kerukunan Beragama Di Indonesia.” Agama, 2013.

Falk, Armin, and Urs Fischbacher. "A Theory of Reciprocity." Games and Economic Behavior, 2006. https://doi.org/10.1016/j.geb.2005.03.001.

Galtung, Johan. "Religions Hard and Soft." In The Ashgate Research Companion to Religion and Conflict Resolution, 2012.

Gambetta, Diego, and Steffen Hertog. Engineers of Jihad: The Curious Connection between Violent Extremism and Education. Engineers of Jihad: The Curious Connection between Violent Extremism and Education, 2016. 
Hasan, Noorhaidi. "Reformasi, Religious Diversity, and Islamic Radicalism after Suharto." Journal of Indonesian Social Sciences and Humanities, 2008.

Heck, Axel. "Images, Visions and Narrative Identity Formation of ISIS." Global Discourse, 2017. https://doi.org/10.1080/23269995.2017.1342490.

Horgan, John. Walking Away from Terrorism: Accounts of Disengagement from Radical and Extremist Movements, 2009. https://doi.org/10.4324/9780203874738.

Kasir, Ibnu. Tafsir Alquran Al Adhim. Juz 4. Beirut: Dar Al Fikr, 2005.

Lugo, Luis, Alan Cooperman, Jessica Hamar Martinez, Besheer Mohamed, Michael Robbins, Neha Sahgal, and Katie Simmons. "The World's Muslims : Unity and Diversity." Pew Research Center, 2012.

Magnis-Suseno, Franz. "Christian and Muslim Minorities in Indonesia.” In Democracy and Islam in Indonesia, 2015. https://doi.org/10.7312/columbia/9780231161916.003.0004.

"Mausu'ah Al Hadis Syarif Fi Kutub Tis'ah." al-Baramij Syirkah islamiyah al Duliyah, n.d. http://www.almeshkat.net/books/open.php?cat=37\&book=2293.

Mazrui, Ali A. "Islam, Political Leadership and Economic Radicalism in Africa." Comparative Studies in Society and History, 1967. https://doi.org/10.1017/S0010417500004539.

O’Neill, Michael. "AA Double Face of False and True': Poetry and Religion in Shelley." Literature and Theology, 2011. https://doi.org/10.1093/litthe/frq067.

Ömer Taşpınar. "Fighting Radicalism, Not 'Terrorism': Root Causes of an International Actor Redefined." SAIS Review, 2009. https://doi.org/10.1353/sais.0.0059.

Pedersen, Lene. "Religious Pluralism in Indonesia." Asia Pacific Journal of Anthropology, 2016. https://doi.org/10.1080/14442213.2016.1218534.

Pieter, Jeneman, and John A Titaley. "Hubungan Antar Agama Dalam Kebhinekaan Indonesia (Studi Kasus Terhadap Hubungan Warga Jemaat GPIB Tamansari Pospel Kalimangli Dengan Warga Muslim Di Dusun Kalimangli)." Waskita: Jurnal Studi Agama Dan Masyarakat, 2013.

Porta, Donatella Della, and Gary LaFree. "Guest Editorial: Processes of Radicalization and de-Radicalization." International Journal of Conflict and Violence, 2012. https://doi.org/10.4119/UNIBI/ijcv.266.

Qurtuby, Sumanto Al. “A Camouflage for Religious Violence.” Jakarta Globe, 2012. 
Rooduijn, Matthijs, and Brian Burgoon. "The Paradox of Well-Being: Do Unfavorable Socioeconomic and Sociocultural Contexts Deepen or Dampen Radical Left and Right Voting Among the Less Well-Off?" Comparative Political Studies, 2018. https://doi.org/10.1177/0010414017720707.

Sabuni, Muhammad Ali. Safwatu Al Tafasir. Jilid 2. Beirut: Dar Alquran Al Karim, 1999.

Sari, Abi Ishaq Ibrahim al. Ma'anil Quran Wa I'rabuhu. Edited by Tahqiq: Abdul jalil Abd Sulbi. Beirut: Alam al Kutub, n.d.

Sayyid Qutb. Tafsîr Fi Zhilâl Al Qur'an. Cairo: Dar as Syuruq, 1992.

Schmid, Alex. "Radicalisation, De-Radicalisation, Counter-Radicalisation: A Conceptual Discussion and Literature Review." Terrorism and CounterTerrorism Studies, 2013. https://doi.org/10.19165/2013.1.02.

Sekulow, Jay. "The Rise of ISIS and the New Caliphate." In Rise of ISIS: A Threat We Can't Ignore, 2014.

Shihab, M. Quraish. Tafsir Al Misbah. Jakarta: Lentera Hati, 2002.

Snow, David, and Remy Cross. "Radicalism within the Context of Social Movements: Processes and Types." Journal of Strategic Security, 2011. https://doi.org/10.5038/1944-0472.4.4.5.

Walton, C. Dale. "A Review of 'Routledge Handbook of Political Islam." Comparative Strategy, 2012. https://doi.org/10.1080/01495933.2012.665726.

Wiktorowicz, Quintan. "Joining the Cause: Al Muhajiroun and Radical Islam.” In Roots of Islamic Rad Icalism, 2004.

Wilke, Thomas. “„Fuck the Gods“: Moral, Religion Und Religiosität," 2019. https://doi.org/10.1007/978-3-658-11747-4_10.

Yoder, Keith J., and Jean Decety. “The Good, the Bad, and the Just: Justice Sensitivity Predicts Neural Response during Moral Evaluation of Actions Performed by Others." Journal of Neuroscience, 2014. https://doi.org/10.1523/JNEUROSCI.4648-13.2014. 